\title{
Numbers, Species Composition and Residency of a Rodent Community in Forest and Field-forest Ecotones ${ }^{1}$
}

\author{
Maria MAZURKIEWICZ \& Ewa RAJSKA-JURGIEL
}

\begin{abstract}
Mazurkiewicz M. \& Rajska-Jurgiel E., 1986: Numbers, species composition and residency of a rodent community in forest and field-forest ecotones. Acta theriol., 32, 25: 413-432 [With 2 Tables \& 8 Figs.]

Community of rodent species in a field-forest ecotone included: Clethrionomys glareolus, Apodemus flavicollis, A. sylvaticus, A. agrarius and Microtus agrestis while in a forest ecotone it comprised C. glareolus, $A$. flavicollis and A. agrarius. Total numbers of rodents in the community as well as population numbers of particular species were more variable from year to year and always lower in the field-forest ecotone than in the forest ecotone. Groups of transient and resident individuals were distinguished in each species on the basis of length of time they spent in the area. In spite of various degrees of residency among the rodent species, they were higher in the forest ecotone than in the field-forest ecotone. The transient individuals in contrast to the resident ones included more males, both sexually active and non-active, and smaller fractions of sexually active and old individuals, mostly females. The transients and residents tended to avoid each other in space.

[Department of Vertebrate Zoology, Institute of Ecology, Polish Academy of Sciences, Dziekanów Leśny, 05-092 Lomianki, Poland]
\end{abstract}

\section{INTRODUCTION}

In any considerations about the effect of heterogeneity of the environment on small rodent populations attention is paid to importance of ecotones and the role they play in shaping population processes and numbers (Andrzejewski, 1983). The ecotone habitats are not precisely defined and thus there are no studies focused on following the changes in population numbers and structure and the processes on rodent community level. The literature on the subject offers only fragmentary data on the effect of ecotone habitats on small rodent populations, obtained on the occasion of solving other problems of theoretical population ecology. For example, it was once stated that populations of small rodents showed uneven distribution over large forested areas (Grant \& Morris, 1971; Cockburn \& Lidicker, 1983). A clustered distribution of rodents is affected not only by quality of food supply offered by particular associations but also their size, spatial structure of vegetation and spatial configurations of its components (Kovalevsky, Karpienko \& Ka-

1 Badania wykonano $w$ ramach problemu RM II 15, temat 01.03.05, koordynowanego przez Instytut Ekologii PAN.

2 present address: Mammals Research Institute PAS, 17-230 Białowieża, Poland. 
tenina, 1971; Kovalevsky \& Korenberg, 1978; Gubar, 1974; Mazurkiewicz \& Rajska-Jurgiel, 1978; Mazurkiewicz, 1984). It is also known that variable densities in various types of forest change with time in both annual cycle (Varšavskij, 1937; Zablockaja, 1957; Marvin, 1959; Andrzejewski, 1963) and from year to year (Chełkowska, 1968; Aulak, 1970; Gubar, 1974). In both cases the increase in rodent population numbers entails a change in distribution from clustered towards more uniform. At lower densities the rodents occupy better (optimal) habitats, and, as density gives up, the rodents take over suboptimal habitats. It is emphasised that ecotones often show higher densities of rodents than the inner parts of adjacent habitats and that they are richer in species (Gubar, 1974; Jensen, 1984).

It seems that in various species it is not only spatial configuration of various habitats that is so important but also the character of transitional zones i.e. the sharp the boundary lines between the habitats are. Studying quantitative and qualitative changes occurring in small rodent populations and communities found in ecotones of various degrees of clearcut transition from one habitat into another may provide information on the effect of ecotones on the population number regulatory processes in heterogenous environment. The aim of this study was to compare species composition, population numbers, and residency in two ecotones different in respect to nature of transition from one habitat to another: fresh forest-alder forest and field-forest ecotones.

\section{MATERIAL, METHODS AND STUDY AREA}

The study was carried out during 1982-1983 in Kampinos Forest, a large forest complex near Warsaw, on two 1.4 hectare plots. On each plot, live-traps were arranged in $15 \times 15 \mathrm{~m}$ distances. In each year, four trapping sessions were carried out, each lasting 7 days and spaced in about 6 weeks intervals.

The data pertaining to rodents were collected by a CMR method. The animals were marked by toe-clipping. During the trapping sessions the traps were checked twice daily (at 9:00 AM 5:00 PM). The identification number of rodent, site identification, sex and reproductive activity (females: vagina opened or closed; males: testes in the scrotum or not) were noted.

The age of each individual was roughly estimated on the basis of body size and pelage colour. This method although bearing considerable error, is the only feasible means for dividing rodents into the classes of adult and young animals when live traps are used. The following reasons backed up the reliability of the method: (1) the estimates were similar in cases of multiple catching of the same individual, (2) there was a shift in body weights of the individuals regarded as old in comparison with those regarded as young. An example of body weight distribution in bank vole is given in Fig. 1.

Both experimental plots were rectangular (4 rows of 16 traps each) and were situ:ated along borderlines between two habitats. Plot A was situated on the border between a large forest complex and a field-meadow area. It was of typical ap- 
pearance for a transitional zone between these two habitats i.e. comparised a mosaic of fields, meadows and two young (20-year old) thickets: pine stand and a mixed forest stand, both on a fresh variety of pine forest sites (Fig. 2).

Plot B was situated inside a forest complex in $400 \mathrm{~m}$ distance from plot A and was positioned along a borderline between a 60-year old pine forest of a fresh variety (Peucedano-Pinetum) and a 50-year old alder wood (Circaeo-Alnetum).

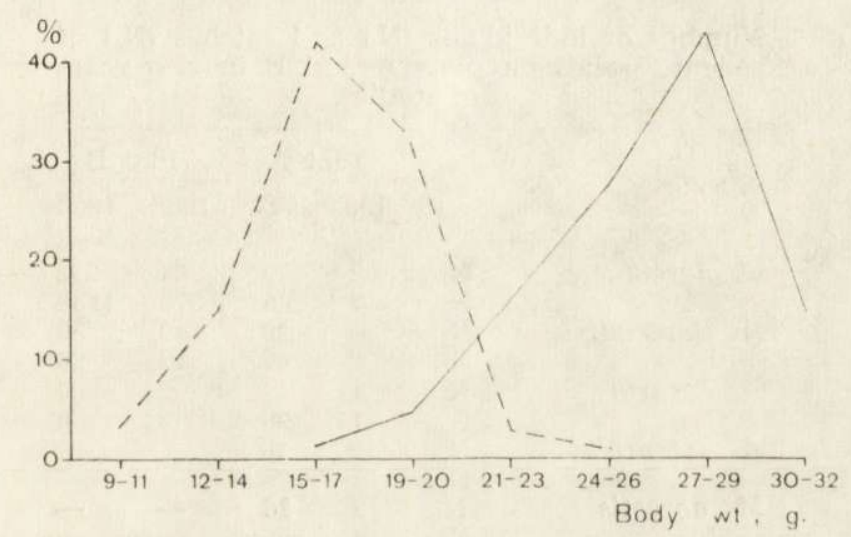

Fig. 1. The distribution of body weight of bank voles assumed old (solid line) or young (broken line).

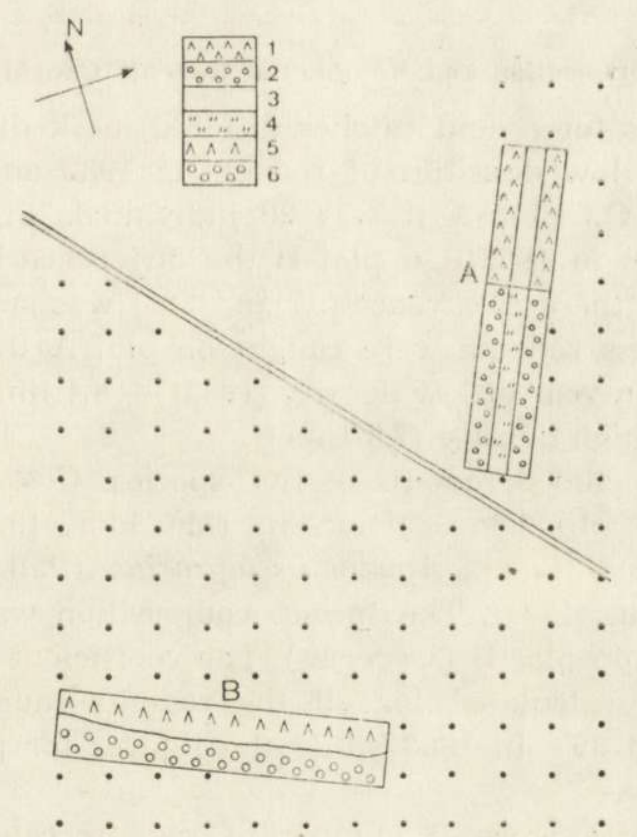

Fig. 2. The situation map of experimental plots A and B. 1 - pine thicket, 2 deciduous thicket, 3 - field, $4-$ meadow, 5 - fresh pine forest, 6 - alder forest. 
The alder wood grew on more moist soil and had less dense herbaceous layer with more undergrowth and trees dominated by deciduous species compared with pine forest with tree component dominated by pine.

The material comprised total of 2134 catches of 584 individuals belonging to 5 rodent species (Table 1 ).

Table 1

Number of individuals $\left(\mathrm{N}_{\mathrm{i}}\right)$ and catches $\left(\mathrm{N}_{\mathrm{c}}\right)$ of rodent species on plots $\mathrm{A}$ and $\mathrm{B}$ in two years of studies.

\begin{tabular}{|c|c|c|c|c|c|}
\hline \multirow{2}{*}{ Species } & & \multicolumn{2}{|c|}{ Plot A } & \multicolumn{2}{|c|}{ Plot B } \\
\hline & & 1982 & 1983 & 1982 & 1983 \\
\hline \multirow[t]{2}{*}{ C. glareolus } & $\mathbf{N}_{\mathrm{i}}$ & 2 & 78 & 84 & 232 \\
\hline & $\mathrm{N}_{\mathrm{c}}$ & 7 & 265 & 370 & 1138 \\
\hline \multirow{2}{*}{ A. flavicollis } & $\mathrm{N}_{\mathrm{i}}$ & - & 28 & 9 & 50 \\
\hline & $\mathrm{N}_{\mathrm{c}}$ & - & 47 & 13 & 86 \\
\hline \multirow[t]{2}{*}{ A. agrarius } & $\mathrm{N}_{\mathrm{i}}$ & 1 & 14 & 2 & 4 \\
\hline & $\mathbf{N}_{c}$ & 1 & 28 & 3 & 8 \\
\hline \multirow[t]{2}{*}{ A. sylvaticus } & $\mathrm{N}_{\mathrm{i}}$ & 12 & 36 & - & - \\
\hline & $\mathrm{N}_{\mathrm{c}}$ & 31 & 70 & - & - \\
\hline \multirow[t]{2}{*}{ M. agrestis } & $\mathbf{N}_{\mathrm{i}}$ & 2 & 26 & - & - \\
\hline & & 4 & 50 & - & - \\
\hline
\end{tabular}

\section{RESULTS}

\subsection{Species Corsposition and Numbers of Rodents Caught in Both Ecotones}

Annual figures for rodent catches differed markedly in the two years of studies, with low densities of rodents in 1982 and high numbers in 1983 (Table 1). On plot A it was 20 individuals in 1982 and 182 (i.e. nine times more) in 1983 . On plot B the difference between corresponding figures for these two years (98 and 288) was smaller (three times). In both years less rodents were caught on plot A than B with the difference greater in year of low density (1982) - 4.4 times less on plot A than in year of high density (1.8 times).

The catches included rodents of five species: Clethrionomys glareolus (Schreber, 1780), Apodemus flavicollis (Melchior, 1834), Apodemus sylvaticus (Linnaeus, 1758), Apodemus agrarius (Pallas. 1771), Microtus agrestis (Linnaeus, 1781). The species composition was richer on plot A ( 5 species) than on plot B (3 species). The coefficient of species diversity (Simpson, 1949) calculated for all the rodents caught on plot A was $73 \%$ in 1982 and $89 \%$ in 1983 while the figures for plot B were 33 and $48 \%$, respectively.

On plot A, with a small number of rodents caught, there was the highest fraction of A.s. $(68 \%)$ with other species sharing evenly in total figures. In 1983 however, C.g. was caught in highest numbers (48\%) again with equal proportions of other species (Table 1). 
On plot B, in both years, C.g. was the dominating species (88 and $81 \%$ ), with A.f. occuring in slightly higher proportion in $1983(17 \%)$ than in $1982(9 \%)$. A.a. occurred in small numbers (Table 1).

\subsection{Seasonal Changes in Numbers and Species Composition of Rodent Community}

The analysis of the seasonal changes in numbers of rodents in the communities on plots $\mathrm{A}$ and $\mathrm{B}$ revealed that in the year of low density there were no rodents on plots in spring months. In July, only one individual was caught on plot A and it was not before August that 14
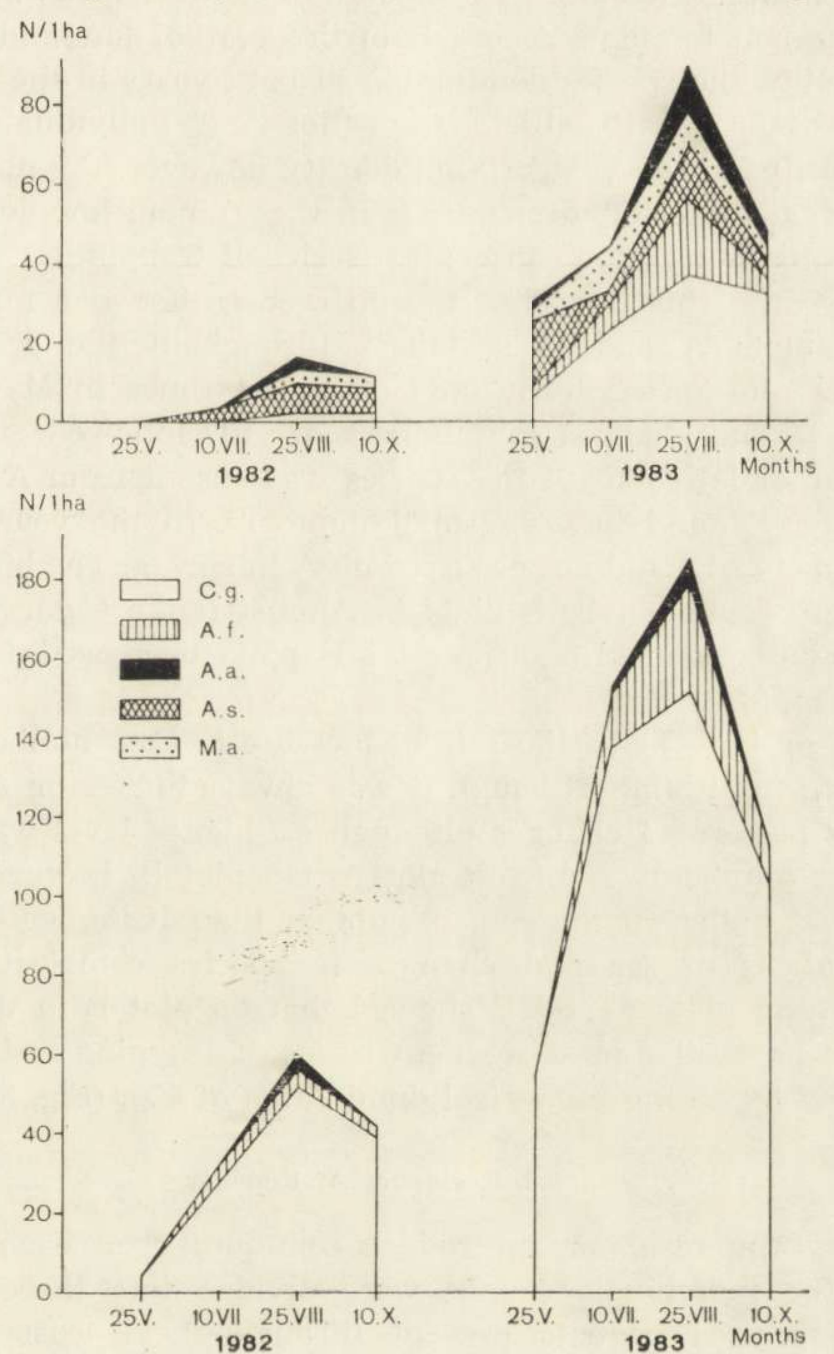

Fig. 3. Dynamics of changes in numbers of rodent community in two years of study on plots A and B. 
rodents were found in the area; it was the maximum number found in 1982 on this plot. On plot B, in spring, the numbers were low (2 individuals) but early in July there were 33 individuals noted. Like on plot A, the peak in rodent numbers occurred in August.

In the year of high density, there were increases in numbers on both plots between May and August, with the highest increment taking place between May and July on plot B (like in the year of low density) while on plot A the maximum numbers occurred between July and August (Fig. 3).

The dynamics of changes in population numbers was studied for the species common for plots A and B in the year of low and high density.

C. glareolus, the species dominating in both years in the forest ecotone (plot B) was practically absent from plot A (2 individuals) in the year of low density. In the year of high density however, the numbers on plot A approached those found on plot B in the year on low density $(0.8 ; 0.8$; $0.7 ; 0.8$ of this number in consecutive series of trapping).

In the year of high density, the differences between numbers of C.g. noted on plots A and B sustained throughout the season although decreasing from spring to autumn (from 8.4 times in May to 3.3 times in October). The changes in numbers of A.f. followed similar pattern. In the year of low density the species was absent from A plot while on $B$ plot it was found in very small numbers. In the year of high population density, A.f. did not occurred on A in spring. The highest numbers of A.f. were found on both plots in August (alike C.g.). The difference between numbers of A.f. on A and B plots decreased from spring to autumn (Fig. 3).

In 1983, on both plots, the rate of increase in C.g. numbers went down from spring to autumn although it was always higher on A plot than on B. Similar pattern of changes although on higher level was followed by increase in numbers of A.f. on plot A. On plot B, however, the rate of increase was higher at the end of summer than at its beginning.

The analysis of seasonal changes in species composition of rodent community on plots A and B showed that on plot B in the contrary to plot $\mathrm{A}$ it was similar in subsequent series of trapping in both years and was marked by strong numerical domination of C.g. (Fig. 3).

\subsection{Residency of Rodents}

To study the residency in rodent community on each experimental plot, all the individuals caught were divided into three groups. First group compraised rodents present throughout at least two series of trapping, second group included rodents that were caught (twice or more) within one series. The two groups represented resident animals. Third 
group encompassed those individuals that were caught only once and no more (transient animals) (Petrusewicz \& Andrzejewski, 1962; Andrzejewski, 1969).

In order to check if appearing of resident and transient (encountered only once) rodents had different course, an analysis of character of the removal during consecutive days of trapping session was attempted separately for C.g. and other species in the community.

Different courses of the removal were found. There was a high rate of removal of C.g. individuals regarded as residents in the initial days
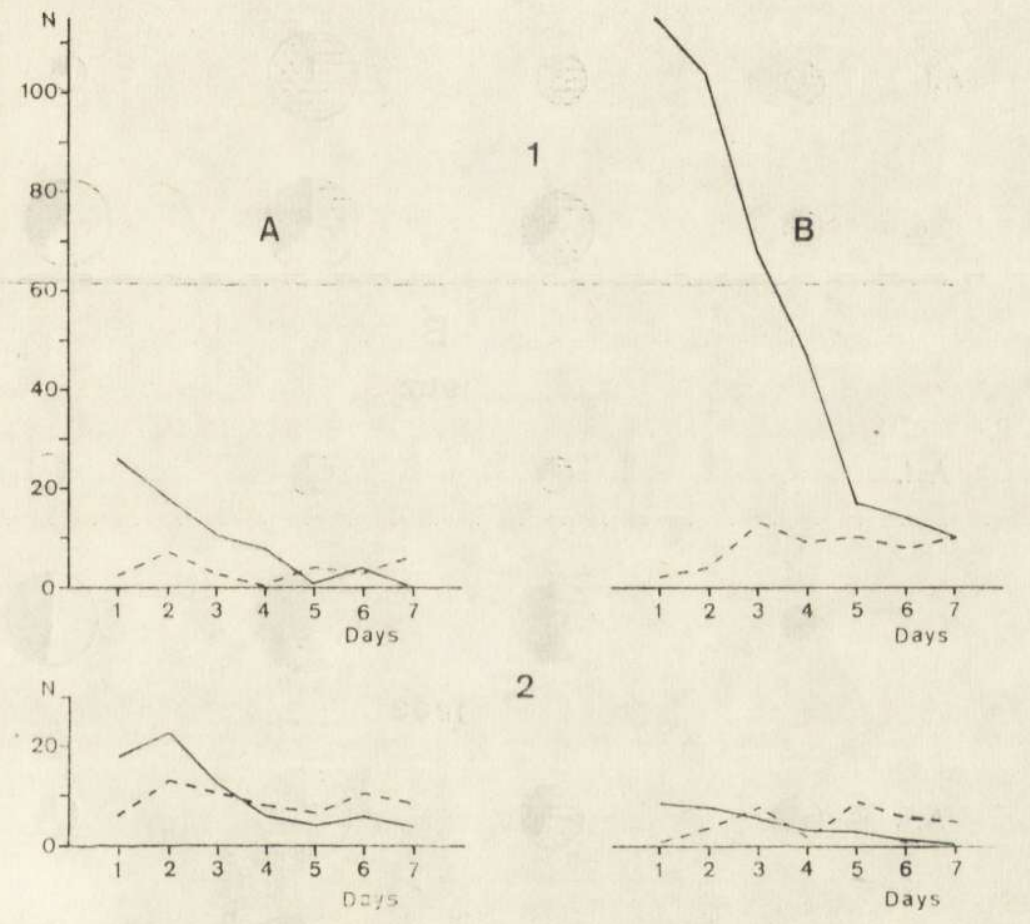

Fig. 4. The removal of resident (solid line) and transient (broken line) C. glareolus (1) and other species (2) in consecutive days of trapping sessions on plots A and B.

of trapping session with next drop and stabilization at a certain level, higher on plot B than on plot A. The rate of removal of the individuals regarded as transients remained uniform throughout the session. Similar patterns were found in other species (Fig. 4).

It has been assumed that dividing rodents into those that stay in the area for long or short period and those that are transient reflects the structure of rodent residency there and forms a sound basis for further analysis. 
The analysis of residency structure for consecutive series of trapping in 1982 and 1983 on plot B and for 1983 for plot A was carried out separately for dominating species C.g. jointly for species common for both plots (A.f., A.a.), and for species present only on plot A (A.s., M.a.).

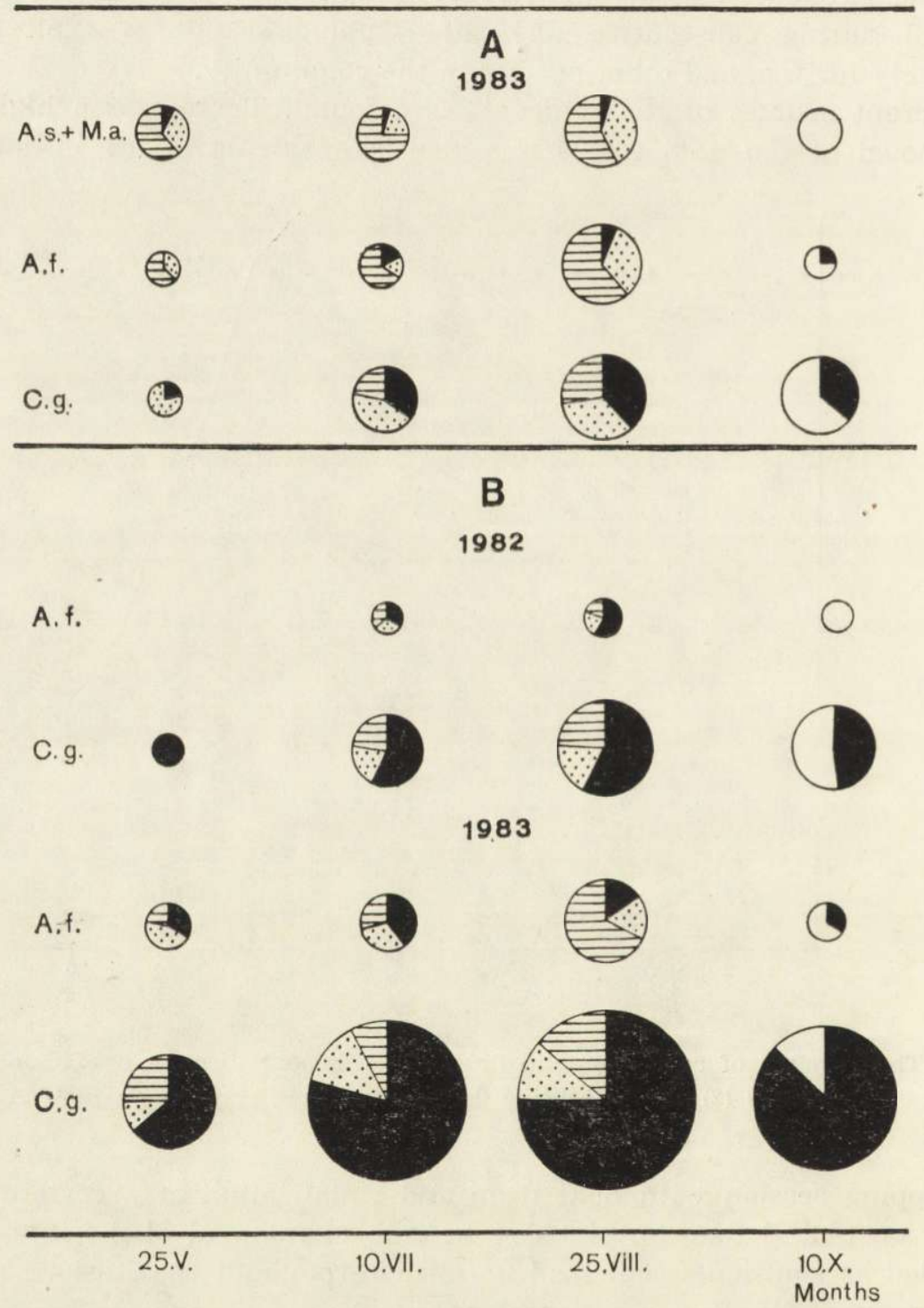

Fig. 5. Residency structure of rodent communities in series of trapping in 1982 and 1983. The area of a circle represents number of rodents. Proportions of various groups of individuals are shown as follows: black - resident for two or more series; dotted - resident in one series; striped - transient; empty - newly marked. 
In the last series of trapping (October) only the animals that were present throughout at least two series were taken into consideration. The remaining group included new individuals that could not be assigned to either resident or migrating group. The statistical significance of differences was assessed by Student's $t$-test and $\chi^{2}$ test.

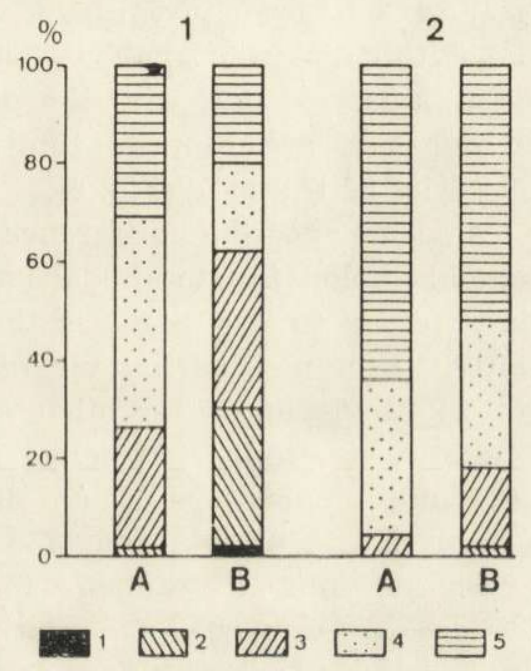

Fig. 6. Residency structure in C. glareolus (1) and other species (2) of the community in 1982 in plots A and B. Percentages of rodents settled for 4, 3, 2, and 1 series of trapping $(1-4)$ and rodents migrating (5).

It was found that on B plot C.g. followed a uniform pattern of residency with high proportions of long-resident animals (75-78\%) throughout the season. To the contrary, on A plot the situation was reversed, with high proportions of short-resident and transient individuals. The difference between proportions of long-resident individual for the two plots was statistically significant at the beginning of season (May-July) as well as at its end (Aug. - Oct.) $(p<0.001)$. The difference in fraction of transients between plots A and B was, at the beginning of the season, close to the limits of statistical significance $(0.1<p<0.05)$ while towards the end of the season it became statistically significant $(0.02<p<0.05)$. Within plot A, an increase of long-resident animals was found at the end of the season $(0.1<p<0.05)$ (Fig. 5$)$.

On plot B, A.f. and A.a. showed an increase in fraction of transient animals at the end of summer $(0.01<p<0.002)$ while on plot $A$ a high proportion of transients was found throughout the season. Nevertheless, towards the end of summer there was some tendency to increase residency. The comparison of the residency in these two species on plots $\mathrm{A}$ and $\mathrm{B}$ revealed significantly higher residency on plot $\mathrm{B}$ at the begin- 
ining of summer $(p<0.001)$ with no significant differences at the end of summer (Fig. 5).

A.s. and M.a. followed similar pattern throughout the season with slight increase in group of short-resident individual at the end of season (Fig. 5).

In order to compare the residency between bank vole and other species both between plots and within them an analysis for bank vole and other species for entire 1983 was carried out, with the group of long-resident individual divided further into subgroups of individuals remaining in the area for 2,3, and 4 series of trapping (Fig. 6).

The material was tested for possible differences between frequency distribution of the animals belonging to the above subgroups between C.g. and the remaining species (test $\chi^{2}$ ). It was then revealed that C.g. had indeed significantly different distribution of frequencies of the subgroups from the distributions found for other species $(p<0.001)$. On both plots bank voles manifest stronger tendency to settle (fractions of long- and short-resident individuals were 69 and $80 \%$ on plots A and B respectively) when compared with other species (36 and 48\% respectively on plots A and B). Yet the comparison made for C.g. between plots revealed significant difference $(p<0.001)$. On plot $B$, there was a high proportion of the animals staying longer $(30 \%$ of them were found in 3 or 4 series of trapping) while on plot A a mere $2 \%$ of individuals were found in 3 series of trapping and no individual was found in 4 series. These differences were statistically significant at $p<0.001$ level (Fig. 7). There were no statistically significant differences in proportions of the subgroups regarding other species on both plots although on plot B a proportion of long-resident animals was significantly higher than on plot A $(0.05<p<0.02)$ (Fig. 6).

The average time of stay in C.g. was significantly longer (12.6 weeks) on plot B than on plot A (8.4 weeks) $(0.02<p<0.01)$. Yet there were no significant differences between average time of stay for other species (plot $\mathrm{A} \longrightarrow 8.7$ weeks, plot $\mathrm{B}-8.0$ weeks).

\subsection{Characteristics of Resident and Transient Animals}

The differences in settlement structure on the two plots may result from different trappability of rodents inhabiting them. The average number of catches during one trapping session was thus determined for a resident individual of C.g. and that of other species on the two plots.

It was found that an overall trappability was low and for C.g. did not exceed $3.23 \pm 2.83$ on plot $\mathrm{A}$, and $2.99 \pm 3.0$ on plot $\mathrm{B}$. The remaining species showed $2.95 \pm 2.83$ and $2.03 \pm 0.89$ catching per individual on plots $\mathrm{A}$ and $\mathrm{B}$ respectively (statistically significant at $0.01<p<0.02$ for C.g.; 
$0.02<p<0.01$ for other species. In A plot the average number of catches of C.g. and other species did not differ significantly while on plot B the trappability of C.g. is significantly higher than that of other species $(p<0.001)$.

The following characteristics were analyzed jointly for two years of study: species composition, sex structure, age structure (dividing into old and young age classes), and reproductive activity, for all the species involved, within the reproductive season (from May to August) and for resident and transient individuals. The characteristics of the residents pertained to the time of their emergence on a plot (i.e. they were new individuals known to stay $1-3$ series of trapping).

The analysis of species composition of residents and transients showed that the proportions of these two groups within the communities on plots A and B differed significantly (at $0.02<p<0.05$ for plot A and $p<0.001$ for plot B). The comparison was made by $\chi^{2}$ test.

On both plots C.g. is the most resident species. Its fraction within residents is significantly higher than that in transients at $0.05<p<0.02$ on $\mathrm{A}$, and $p<0.001$ on $\mathrm{B}$ ). The proportions of other species in resident and transient groups did not differed significantly on plot A while on plot B there was significantly more A.f. among transients than among residents $(p<0.001)$. The proportion of A.f. among transients is also significantly higher on plot $\mathrm{B}$ than on plot $\mathrm{A}(0.02<p<0.05)$ while its proportions among residents are the same (Fig. 7).

A

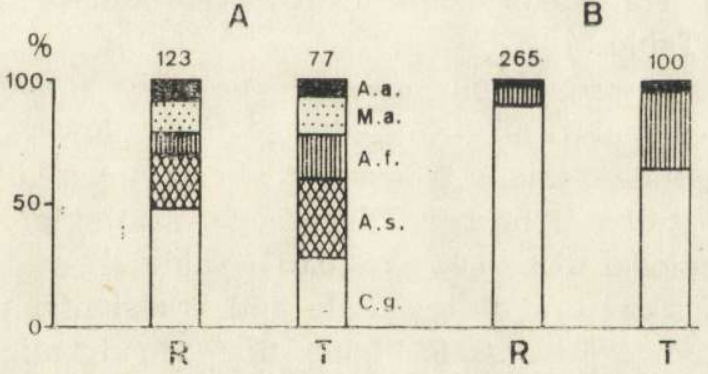

Fig. 7. Species composition of resident rodents $(R)$ and transients $(T)$ on plots A and B. Numbers above bars denote sample sizes.

In order to compare sex structure, reproductive activity and age structure among groups of residents and transients belonging to particular species the data from both plots were pooled.

The sex ratios in resident C.g. A.f. and A.a. was close to $1: 1$ whereas in A.s. there was a deficiency of males, and in M.a. a surplus of males. Higher proportions of males were found in transients of all species 
except M.a. when compared with residents. The differences were statistically significant for A.f. $(0.02<p<0.05)$ and A.s. $(p<0.05)$ while in C.g. the difference was close to the limits of significance. Similar tendencies were found in groups of reproductively active and inactive

Table 2

Sex ratio, age structure and proportion of reproductively active animals among resident $(\mathrm{R})$ and transient $(\mathrm{T})$ rodents of five species.

\begin{tabular}{|c|c|c|c|c|c|c|}
\hline \multirow[t]{2}{*}{ Species } & & \multirow[t]{2}{*}{$\begin{array}{c}\text { Percentages } \\
\text { of males }\end{array}$} & \multicolumn{2}{|c|}{$\begin{array}{l}\text { Percentages } \\
\text { of old animals }\end{array}$} & \multicolumn{2}{|c|}{$\begin{array}{c}\text { Percentages of } \\
\text { reproductively } \\
\text { active }\end{array}$} \\
\hline & & & 우 우 & $\sigma^{x} \sigma^{x}$ & 우 & $\sigma^{x} \sigma^{x}$ \\
\hline C. glareolus & $\mathbf{R}$ & 53 & 27 & 26 & 40 & 36 \\
\hline $\mathrm{N}=396$ & $\mathrm{~T}$ & $66^{1}$ & $7^{1}$ & 17 & 24 & 23 \\
\hline A. flavicollis & $\mathrm{R}$ & 47 & 58 & 65 & 58 & 75 \\
\hline $\mathrm{N}=87$ & $\mathrm{~T}$ & $77^{1}$ & $20^{1}$ & 38 & 30 & $44^{1}$ \\
\hline A. sylvaticus & $\mathrm{R}$ & 32 & 40 & 100 & 60 & 100 \\
\hline $\mathrm{N}=69$ & $\mathrm{~T}$ & $63^{1}$ & 25 & 30 & 25 & 50 \\
\hline A. agrarius & $\mathrm{R}$ & 50 & 66 & 70 & 66 & 100 \\
\hline $\mathrm{N}=21$ & $\mathrm{~T}$ & 80 & 33 & 29 & 33 & 60 \\
\hline M. agrestis & $\mathrm{R}$ & 80 & - & 100 & 100 & 100 \\
\hline $\mathrm{N}=28$ & $\mathrm{~T}$ & 67 & 60 & 70 & 100 & 80 \\
\hline
\end{tabular}

${ }^{1} p<0.001$

animals i.e. there was more males among transients than in residents (the difference was statistically significant in reproductively inactive A.f. at $0.02<p<0.05$ ) (Table 2).

The comparison of proportions of reproductively active and inactive animals among residents and transients revealed lower proportion of active males and females among transients when compared with residents (there was statistically significant difference in the group of reproductively active males of A.f., $0.02<p<0.01$ ) (Table 2).

As regards age structure of residents and transients, the proportion of old females among residents is higher than among migrants $(p<0.01$ for C.g.; and $0.01<p<0.02$ for A.f.). Similar tendency occurred in males except in C.g. where fractions of old males were similar (and low) among both groups of individuals (Table 2).

The above comparisons indicate that the differences in sex ratio, proportion of reproductively active animals and age structure follow similar patterns among resident and transient parts of populations irrespective of species. In contrast to resident rodents the transient individuals have higher proportions of males both reproductively active and inactive, and smaller proportions of reproductively active and old individuals, most of all, females. 
In each series of trapping (provided that the number of catches was sufficiently high) the distribution of catches was noted in every trap site separately for residents and transients of C.g. and other species. The following index was used:

$$
\mathrm{V}=\frac{\delta^{2}}{\bar{x}}
$$

where: $\bar{x}$ - average number of individuals caught at a trap site; $\delta^{2}-$ variance of such average.

The statistical significance of deviation from random distribution was tested by Student's t-test. It was found that on plot A during the 1983 season the resident individuals of C.g. and other species were distributed in clusters $(p<0.02)$ while the transients were, in most cases, distributed randomly. On plot B, residents of C.g. were distributed in clusters $(0.01<p<0.02)$ in all trapping series in both years except in August 1982 (random distribution). The residents of remaining species were distributed randomly throughout 1982 but in May and August 1983 the distribution was clustered $(0.01<p<0.02)$ with random distribution in July. The distribution of transients belonging to all remaining species was random in all the series.

It was also tested whether the residents and transients avoid each other at trap sites. A co-occurrence analysis was completed for: (1) resident and transient individuals of C.g., (2) resident of C.g. and transients from other species, (3), resident and transient individuals of A.f., A.a., A.s., and M.a.

Owing to small volume of data the calculations for plot A were completed on pooled data from two years. On plot B the analysis of co-occurrence of resident C.g. and transient C.g., A.f. and A.a. was carried out separately for 1982 season, early summer (May-July) of 1983, and late summer (August) of 1983. The co-occurrence of residents and transients of other species was studied jointly for all the series of trapping.

On plot $\mathrm{A}$ in all the cases considered there were negative correlations between numbers of residents and transients at particular trap sites (correlation coefficients significant at $p<0.001$ ). Similar situation occurred on plot B except in August 1983 when no correlation was found between occurrence of resident C.g. and all transient rodents (C.g. and other species). The negative correlations found between residents and transients of all groups were statistically significant $(0.01<p<0.02)$. 
In order to test whether individuals regarded as short resident and transient were not in fact animals settled beyond plot i.e. of small chance of being caught, an analysis of percentage distribution of short- and long-resident and transient individuals caught on rows of traps (across ecotone) was attempted. It was found that the distribution of rodents on rows running across ecotone did not show any "edge effect" i.e. more catches on outermost sites, perhaps with exception of C.g. on plot B. It would mean that the individuals of this species showed more pronounced tendency to settle that this estimated in forest ecotone (Fig. 8).

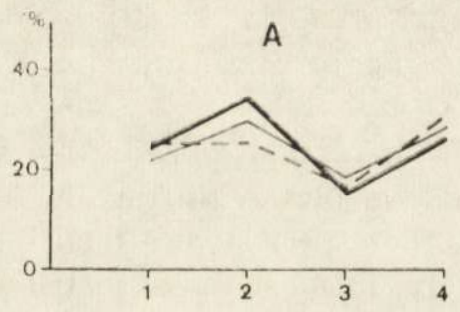

1

B

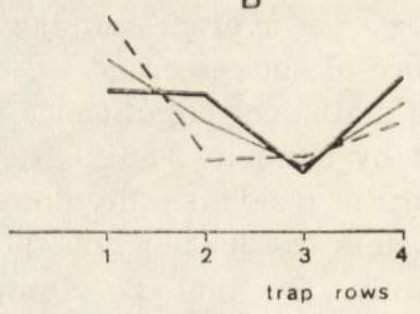

2
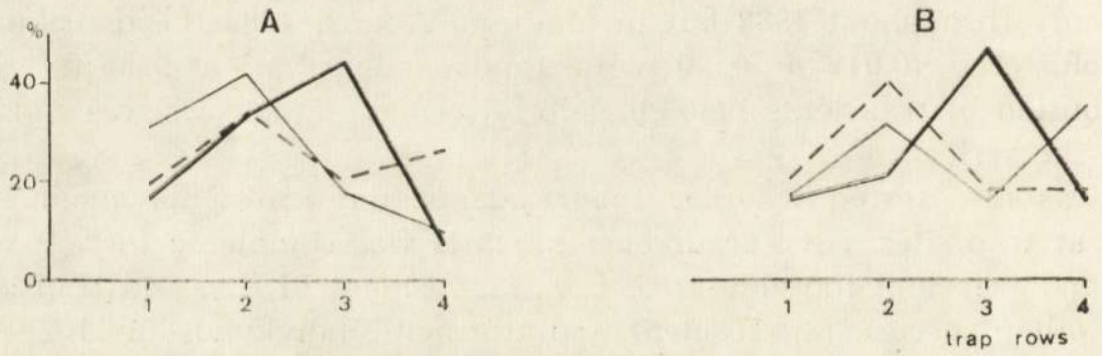

Fig. 8. Percentages of individuals of C.g. (1) and other species (2) caught on rows of traps on plots A and B. Long-resident individuals - thick solid line; short-resident - thin solid line; transient - broken line.

\section{DISCUSSION}

The above results describe the numbers, species composition and residency of components of rodent communities inhabiting two different ecotones. The forest ecotone is an example of a gradual transition of alder forest habitat into a pine forest one, both remaining close to an optimal habitat for C.g. and A.f., Yet the differences between these forest habitats including species composition of tree stand and the spatial structure may influence both species composition and numbers of rodents (Mazurkiewicz, 1984; Mazurkiewicz \& Rajska-Jurgiel, 1978; van Horne, 
1982; Miller \& Getz, 1977; Jensen, 1984 and others). The second experimental plot represents a clearcut transition between forest and fieldmeadow habitat. Owing to its environmental diversity characteristic for such ecotones, the second area could support both forest and meadow species.

The suitability of a habitat to a given species of rodents is often assessed by actual number attained by the species (Gubar, 1974; $\mathrm{Mc}^{\circ} \mathrm{Cl}$ loskey, 1981, Wołk \& Wołk, 1982; Mazurkiewicz, 1984; Mazurkiewicz \& Rajska-Jurgiel, 1978). Some authors suggest however, that it is the structure of a population living in a given habitat that best reflects variable living conditions there (Viitala, 1977; Wiger, 1982; van Horne, 1983). It seems that no less but simultaneous estimate of numbers, population structure and their changes can provide full information on the relationship between a population or community and its environment.

The field-forest ecotone showed more diverse and variable species composition of rodent community than the forest ecotone. Most of the seasonal changes in the field-forest ecotone followed irregular changes in numbers of two species (A.f. and A.a.). They might have been brought about by seasonal changes in habitat preferences displayed by these species (Rajska-Jurgiel \& Mazurkiewicz, in prep.). Overall numbers have also been more variable (between years of low and high densities) in the field forest ecotone than in the forest one.

C.g., a species dominating in forests was, in the year of low density, practically absent from field-forest ecotone while in the year of high density attained numbers close to low density year figures in the forest ecotone. Higher rate of population growth of C.g. in field-forest ecotone and closing the gap between the densities in two ecotones indicate a tendency to increase migration and taking over poorer habitats when the optimal ones are densely inhabited. This agrees well with reports by many authors (Grant \& Morris, 1971; Gubar, 1974; Mc'Closkey 1981): Similar pattern of changes has been observed for A.f.

In order to determine the residency of the communities inhabiting the two ecotones, all rodents have been divided into residents and transients (Andrzejewski, 1969; Petrusewicz \& Andrzejewski, 1982). The residency estimates might bear errors derived from size and elongated shape of plots that could, in many cases, only overlap the peripheral parts of individual ranges thus lessening the chance of catching. The size of plots used in this study is regarded as sufficient in studies of C.g. and A.f. populations (Pelikán, 1971; Babińska, 1972; Gliwicz, 1981). The effect of elongated shape should manifest itself in strong "edge effect" but there was none on either plots. Thus the method described above seems justified for studies of residency of rodents particularly as it is used 
for comparison between two different ecotones rather than for absolute estimates.

The comparison of characteristics of residents and transients of various species indicate that status of an individual resident or transient may be of more importance that its allegiance to a particular species. In both C.g. and the remaining species during subsequent days of trapping there were similar numbers of transients, while in dynamics of catching of resident individuals a gradual decline can be observed as trapping progresses. The transient individuals have tendency to distribute randomly over the area and to avoid resident individuals of their own species as well as those of other species. Similar results were obtained by Rajska-Jurgiel (1976). The resident individuals of C.g. are distributed in clusters while rodents of other species are distributed in clusters in field-forest ecotone and in random fashion in forest ecotone.

The sex structure, reproductive activity structure and age structure of residents and transients of particular species differentiate in similar way these two large groups (although the differences have not always been significant) regardless of species. In comparison to residents, the transients have higher proportions of males, in both active and inactive classes, and lower proportions of reproductively active individuals and old ones, most of all, females. All this agrees with data reported by other authors (Kozakiewicz, 1976; Gaines \& McClenaghan Jr., 1980).

The comparison of species composition revealed that C.g. is the most resident component of the community. A strong tendency of this species to become settled has earlier been indicated by many authors (Naumov, 1951; Nikitina, 1971; Koshkina et al., 1972). Proportions of another species in the pools of resident or transient individuals are similar in field-forest ecotone while in the forest ecotone a high proportion of A.f. has been noted among transients.

Despite the differences in residency in various species there is generally stronger tendency to settle in the forest ecotone than in field forest ecotone. It regards mainly long-resident animals whose proportions in both C.g. and A.f. are higher in forest ecotone. High degree of residency in the forest ecotone may stem from the fact that neighbouring forest habitats may be equally suitable for rodents. In case of C.g. this may be associated with high occurrence of shrubs, similar in both habitats. This is known to be a key factor in settling and reaching high numbers by C.g. (Wiger, 1982; Mazurkiewicz, 1984). There are some data indicating that in close forest habitats might be such differences in understory vegetation that could prove to be an ecological barrier for C.g. This may result in large differences in population numbers between these habitats and with an increase in numbers the number of individuals 
getting caught on the boundary increases. Yet the population numbers do not show a tendency to get equal (Jensen, 1984; Mazurkiewicz, unpublished data). No such phenomenon has been observed in A.f. (Jensen, 1984). It might be implied by strong, tendency to migrate found in this study, associated presumably with type of food and the spatial structure of A.f. populations.

The field-forest ecotone is a specific habitat which may offer living conditions to forest, field and meadow species. Yet all the species living here show low tendency to settle; this may suggest that such ecotone offers rather suboptimal conditions for rodents. Thus it is not a place for permanent settlement, and when more optimal habitats are densely populated the ecotone supports ever rotating fauna of rodents.

Moreover, according to Goszczyński (1985), the field-forest ecotone may be an "ecological trap" for rodents because of its intensive penetration by predators. It could be that short time of presence there results from lower survival of rodents in this ecotone in comparison to the forest one.

The presented results show that the character of transition zone (i.e. how sharp the boundary lines are) forms an important element of habitat structure. This may not simply mirror but actually shape the processes in population and affect its continuity. Since under condition of heterogenic environment the extent of ecotone effect upon differentiation of small rodent population structure and numbers within various parts of ecotone may be fairly significant, the continuation of such studies seems purposeful.

\section{REFERENCES}

1. Andrzejewski R., 1963: Processes of incoming, settlement and disappearance of individuals and variations in the numbers of small rodents. Acta theriol., 7: $169-213$.

2. Andrzejewski R., 1969: Analysis of results of catches of small mammals by the "Calender of Catches" method. Zesz. Nauk., 2: 1-194. Warszawa [In Polish with English summ.].

3. Andrzejewski R., 1983: Searching for the theory of physiocenosis. Wiad. ekol.. 24: 93-125 [In Polish with English summ.].

4. Aulak W., 1970: Small mammal communities of the Białowieża National Park. Acta theriol., 15: $465-515$.

5. Babińska J., 1972: Estimation of rodent consumption on meadow ecosystem belonging, to the community of Molinietalia order. Ekol. pol., A, 20: 747-761.

6. Chełkowska H., 1969: Numbers of small rodents in five plant associations. Ekol. pol., A, 17: 847-854.

7. Cockburn A. \& Lidicker W. Z. J., 1983: Microhabitat heterogenity and population ecology of an herbivorous rodent Microtus californicus. Oecologia, 59: $167-177$. 
8. Gaines M. S. \& McClenaghan Jr., 1980: Dispersal in small mammals. Ann Rev. Ecol. Syst., 11: 163-196.

9. Gliwicz J., 1981: Competitive interactions within a forest community in Central Poland. Oikos, 37: 353-362.

10. Goszczyński J., 1985: The effect of structural differentiation of ecological landscape on the predator-prey interaction. Treatises and Monographs. Warsaw Agricultural University: 1-80. Warszawa [In Polish with English summ.].

11. Grant P. R. \& Morris R. D., 1971: The distribution of Microtus pennsylvanicus within grassland habitat. Can. J. Zool., 7: 1043-1051.

12. Gubar J. P., 1974: The habitats of the northern red-backed bank vole (Clethrionomys rutilus Pall.) on the Onega peninsula. Fauna \& Ecol. Ziv., Nauka, Moskva: 174-188 [In Russian].

13. Jensen T. S., 1984: Habitat distribution, home range and movements of rodents in mature forest and before stations. Acta Zool. Fennica, 171: 305-307.

14. Joule J. \& Cameron G., 1975: Species removal studies. I. Dispersal strategies of sympatric Sigmodon hispidus and Reithrodontomys fulvescens populations. J. Mammal., 56: 378-396.

15. Koshkina T. V., Okulova N. H. \& Aristova A. V., 1972: Territorial relationship among rodents and their role in the regulation of population density. Fund. Probl. Theriol., Nauka: 215-237. Moskva.

16. Kovalevsky Yu. V., Karpenko A. S. \& Katenina N. D., 1971: [Methods of largescale mapping of the distribution and abundance of small forest rodents]. Fauna and Ecology of the Rodents, 10:172-186 [In Russian with English summ.].

17. Kovalevsky J. V. \& Korenberg E. J., 1976: The determination of the norm of quantitative accounts of forest Muridae under the large-scale mapping of their distribution. Zool. Ž., 7: 1079-1085 [In Russian with English summ.].

18. Kozakiewicz M., 1976: Migratory tendencies in population of bank voles and description of migrants. Acta theriol., 21: $321-338$.

19. Marvin M. J., 1959: Myševidnye gryzuny okrestnostej Krasnoufimska. Trudy Ural. otd. MOIP, 2: 43-53.

20. M'Closkey R. T., 1981: Microhabitat use in coexisting desert rodents the role of population density. Oecologia (Berl.), 50: 310-315.

21. Mazurkiewicz M., 1984: Population density of small rodents as affected by chosen elements of tree stand structure. Bull. Acad. pol. Sci., Cl. II, 32: 209-217.

22. Mazurkiewicz M. \& Rajska-Jurgiel E., 1978: Size and structure of rodent community of various forest stand types. Bull. Acad. Pol. Sci., Cl. II, 26: $669-677$.

23. Niller D. H. \& Getz L. L., 1977: Factors influencing local distribution and species diversity of forest small mammals in New England. Can. J. Zool., 5: $159-180$.

24. Naumov N. P., 1951: Novyj metod izučenija ekologii melkih lesnyh gryzunov, Fauna and Ecology of the Rodents, 4: 3-21.

25. Nikitina N. A., 1970: On permanency in the use of territories by rodents. Fauna and Ecology of the Rodents, 9: 110-134. [In Russian with English summ.].

26. Pelikán J., 1971: Quadrat size and density estimates of small mammals. Zool Listy, 20: 139-152.

27. Petrusewicz K. \& Andrzejewski R., 1962: Natural history of a free-living pop. ulation of house mice (Mus musculus Linnaeus) with particular reference to groupings within the population. Ekol. pol. A, 10: 85-102. 
28. Rajska-Jurgiel E., 1976: Interactions between individuals of a population of the bank vole, Clethrionomys glareolus (Schreber, 1780). Ekol. pol. A, 24: $3-35$.

29. Simpson G. G., 1949: Measurement of diversity. Nature, 163: 688.

30. Van Horne B., 1982: Niches of adult and juvenile deer mice (Peromyscus maniculatus) in seral stages of coniferous forest. Ecology, 63: 992-1003.

31. Van Horne B., 1983: Density as a misleading indicator of habitat quality. J. Wildl. Manage. 47: 893-901.

32. Veřavskij S. N., 1937: Zakonomernosti sezonnyh peredviženij myšvidnyh gryzunov. Zool. Ž., 16: 362-392.

33. Viitala J., 1977: Social organization in cyclic subarctic populations of the Clethrionomys rufocanus and Microtus agrestis. Ann. Zool. Fenn., 14: 53-93.

34. Wiger R., 1982: Roles of self-regulatory mechanisms in cyclic population of Clethrionomys with special reference to C. glareolus; a hypothesis. Oikos, 38: $60-71$.

35. Wolk E. \& Wolk K., 1982: Responses of small mammals to the forest management in the Białowieża Primeval Forest. Acta theriol., 27: 45-59.

36. Zablockaja L. V., 1957: Fauna myševidnyh gryzunov v razliěnyh tipah lesa loveberežija širotnogo te enija r. Oki. Biul. mosk. Obšč. Ispyt Prir., Ctd. Biol., 62, 4: 19-36.

Received 4 April 1985, Accepted 10 June 1987.

Maria MAZURKIEWICZ i Ewa RAJSKA-JURGIEL

\section{LICZEBNOSC, STRUKTURA GATUNKOWA I OSIADLOSC ZGRUPOWANIA GRYZONI W EKOTONIE LEŚNYM I POLNO-LESNYM}

\section{Streszczenie}

W dwu ekotonach różniących się ostrością granic między środowiskami (Ryc. 2) zbadano sezonowe zmiany liczebności, struktury gatunkowej i osiadłości zgrupowania gryzoni w latach $1982-1983$.

Stwierdzono, że w ekotonie polno-leśnym zgrupowanie gryzoni tworzyło 5 gatunków: Clethrionomys glareolus, Apodemus flavicollis, A. sylvaticus, A. agrarius i Microtus agrestis. W ekotonie leśnym (bór świeży-lęg) występowały trzy gatunki gryzoni: C. glareolus, A. flavicollis i A. agrarius (Tab. 1).

Struktura gatunkowa zgrupowania gryzoni w ekotonie leśnym była podobna w kolejnych seriach polowu obu lat i charakteryzowała się dominacją C. glareolus. W ekotonie polno-leśnym struktura gatunkowa zmieniała się sezonowo i między latami (Ryc. 3).

Liczebność gryzoni byla wyższa w ekotonie leśnym niż w ekotonie pole-las, przy czym różnica ta była większa w roku niskiej liczebności (Ryc. 3).

$\mathrm{Na}$ podstawie czasu przebywania na powierzchniach wyróżniono dla poszczególnych gatunków grupy osobników osiadlych i migrujących. Porównanie wylowu tych dwu grup osobników wykazało, że w odróżnieniu od migrantów ujawniających się przez cały czas trwania serii połowów, większość osobników osiadłych ujawnia się w pierwszych dniach serii polowów (Ryc. 4). 
Analiza struktury osiadłości gryzoni wykazała, że w ekotonie polno-leśnym przeważają osobniki krótko-osiadłe i migrujące a w ekotonie leśnym - osobniki długo-osiadłe (Ryc. 5, 6). Różnica ta dotyczy także C. glareolus, gatunku mającego istotnie większy udział w grupie osobników osiadłych w stosunku do migrantów (Ryc. 7).

Osobniki migrujące w stosunku do osobników osiadłych charakteryzują się większym udziałem samców, zarówno wśród aktywnych jak i nieaktywnych płciowo gryzoni oraz mniejszym udziałem osobników aktywnych płciowo i starych, przede wszystkim samic (Tab. 2). Osobniki osiadłe i migrujące wykazują tendencję do wymijania się $\mathrm{w}$ przestrzeni. 